\title{
Noise Impact Assessment Using Corine Land Cover Methodology: A Case Study in Funza, Colombia
}

\author{
Miguel De Luque-Villa ${ }^{1,2 *}$, Camila Acosta-Santos ${ }^{3}$, Andrea Vargas-Cediel $^{1}$, Daniel Robledo-Buitrago ${ }^{1,3}$ \\ ${ }^{1}$ Grupo Cundinamarca Agroambiental, Facultad de Ciencias Agropecuarias, Universidad de Cundinamarca, Fusagasugá \\ 252211, Colombia \\ ${ }^{2}$ Departamento de Ecología y Territorio, Facultad de Estudios Ambientales y Rurales, Pontificia Universidad Javeriana, Bogotá \\ D.C. 110231, Colombia \\ ${ }^{3}$ Seruans Environment S.A.S, Calle 16i 102-31 Bogotá D.C, Colombia
}

Corresponding Author Email: mdeluque@ucundinamarca.edu.co

https://doi.org/10.18280/ijsdp.150609

Received: 12 December 2019

Accepted: 10 July 2020

\section{Keywords:}

airport noise, Corine land cover, environmental noise, Funza - Colombia, noise mapping, traffic noise

\begin{abstract}
The spatial distribution of sound pressure levels was analyzed in Funza, Colombia. This survey allowed the identification of several noise sources linked to human activities in the area. To accomplish this, 52 sampling points were distributed all over Funza; measurements were done during day and night time according to environmental regulations. With the sound pressure levels of each point an environmental noise map was generated for both, day and night time. This map was generated with the software ArcGIS 10.5 and compared with regulations. Compliance of environmental noise in Funza was evaluated with a land use cover map; this map was made applying Corine Land Cover methodology adapted to Colombia. Results obtained showed that, during day time $18 \%$ of the Funza area complied, while at night time is only $9.6 \%$. The low percentage of compliance is related to high traffic in the main roads that flows to Bogota; in addition to El Dorado airport landing route located South West of Funza.
\end{abstract}

\section{INTRODUCTION}

Nowadays, noise pollution is one of the most significant environmental problems that contemporary societies face. Noise pollution has become one of the major pollutants in modern cities [1, 2]. Within the main sources of noise found in cities are railways, airports, industries, and traffic. The latter is considered the source that most affects people, especially in areas with high population density [3]. Similarly, in recent years the local population has become very noise-conscious due to the exponentially growing air traffic [4].

About $50 \%$ of the European population lives in noise polluted areas. Approximately $40 \%$ of the population in the European Union is exposed to traffic noise with sound pressure levels above $55 \mathrm{~dB}(\mathrm{~A})$. Whilst, during the day around $20 \%$ of the population is exposed to more than $65 \mathrm{~dB}(\mathrm{~A})$ [5]. In Colombia for Bogotá city, sound pressure levels were measured between 70.8 and $82.3 \mathrm{~dB}(\mathrm{~A})$ in Chapinero neighborhood while values between 76.3 and $84.3 \mathrm{~dB}(\mathrm{~A})$ were measured in Puente Aranda neighborhood [6]. In Medellin city, the assessment of noise levels is part of the Metropolitan Development Plan of Valle de Aburrá. In this area, daytime noise levels range between 65 and $80 \mathrm{~dB}(\mathrm{~A})$ whilst night time levels range between 65 and $76 \mathrm{~dB}(\mathrm{~A})$. In other sectors of the metropolitan area night time noise levels reach $80 \mathrm{~dB}(\mathrm{~A})$ [7].

Constant exposure to noise causes several health effects such as respiratory, cardiovascular, digestive, visual, and endocrine diseases [8]. It can also affect body systems such as the nervous system. Additionally, noise can affect reading, focus, problem- solving, and memory [9].
According to the European Commission, constant exposure to noise alters sleep patterns, affects children's cognitive development, and causes psychosomatic illnesses [8]. Loud noises, regardless of their duration, cause fatigue in auditory sensory cells and temporary hearing loss. Also, some people may be prone to hearing loss as a consequence of noise, genetic predisposition, chronic diseases (e.g. diabetes) and exposure to tobacco smoke [10].

In Colombia, there are agencies in charge of the environment quality control as well as assessments and activities related to compliance of national regulations. Several complaints related to noise pollution have been made during lasts years. For this reason, investments have been made in order to understand the behavior of this pollutant [11].

In order to reduce the effects of environmental noise on areas with large population $(>100,000$ inhabitants, the European Union through Directive 2002/49/EC, defined a common integrated approach to prevent exposure of the population to high levels of noise [2].

In order to develop strategies to mitigate the adverse effects of noise pollution, it is important to understand how the noise pollution behaves in a particular zone. Noise mapping has been suggested for the development of such policies for effective noise assessment and proper noise reduction [12, 13]. Noise maps are the most common tool to achieve this as it helps to assess the efficiency of short, medium and long term corrective actions. These maps are important tools for urban planning, land use management, and identification of sensitive areas to noise caused by specific activities or infrastructure [14]. Spatial distribution of noise levels is important to assess 
the impacts of noise on human health. This allows us to identify which sources of noise are causing damage and prioritize strategies to mitigate the effects on human health.

Uses of land and landscape are considered in current research to estimate noise levels in cities [15-18]. The aim of this work was to analyze the spatial distribution of sound pressure levels in Funza, Cundinamarca. This using day and night time noise maps, as well as noise dynamic through land use cover maps. Additionally, it was evaluated which zones compliance with environmental regulations.

\section{METODOLOGY}

\subsection{Study area}

The city of Funza is located in Department of Cundinamarca at coordinates $4^{\circ} 43^{\prime} 3$ " N, $74^{\circ} 12^{\prime} 34^{\prime \prime} \mathrm{W}$, with an elevation of 2548 meters above sea level and an average temperature of $14^{\circ} \mathrm{C}$. The municipality has a total of 103,509 inhabitants.

\subsection{Characterization of environmental noise}

A quick assessment in the municipality of Funza was done during one day. During this assessment the main noise sources were identified in the study area (e.g., main roads, El Dorado international airport, and high commercial activity) as well as the sensitive receptors to noise (e.g., residential areas, hospitals, schools, development centres and libraries). Facilities and human settlements were absent in the rural area.

There were 52 sites monitored from 2019-03-01 to 201903-31, during day (7:01 to 21:00) and night (21:01 to 7:00) according to Ministerio de Ambiente y Desarrollo Sostenible en Colombia (2006) [19]. All the sampling points (Figure 1) were georeferenced and describe at least one land use cover according to the Corine Land Cover classification system adapted to Colombia [16]. Zones, subzones and maximum noise levels allowed are described in Table 1.

In each sampling point the measurements were carried out with a sound level meter PCE - 428 class II (calibrated to 94 $\mathrm{dB}$ ) placed $4 \mathrm{~m}$ height from the ground. Each measurement last 15 minutes and was composed of five partial measurements. Each partial measurement corresponded to the direction of the microphone (North, South, East, West, and upwards) for three minutes. During the measurements the microphone was protected with a wind screen and was placed on a tripod. Additionally, wind speed was measured with a Topker GM8908 anemometer verifying that this last one don not exceed $3 \mathrm{~m} / \mathrm{s}$. The data collected were analyzed with the software Post-Processor SLM file - PCE 1.6, this is acoustical measurement and analysis software, this is developed based on ISO standard requirements. Finally, data were classified according to maximum allowed environmental noise levels $\mathrm{dB}(\mathrm{A})$ (Table 1)
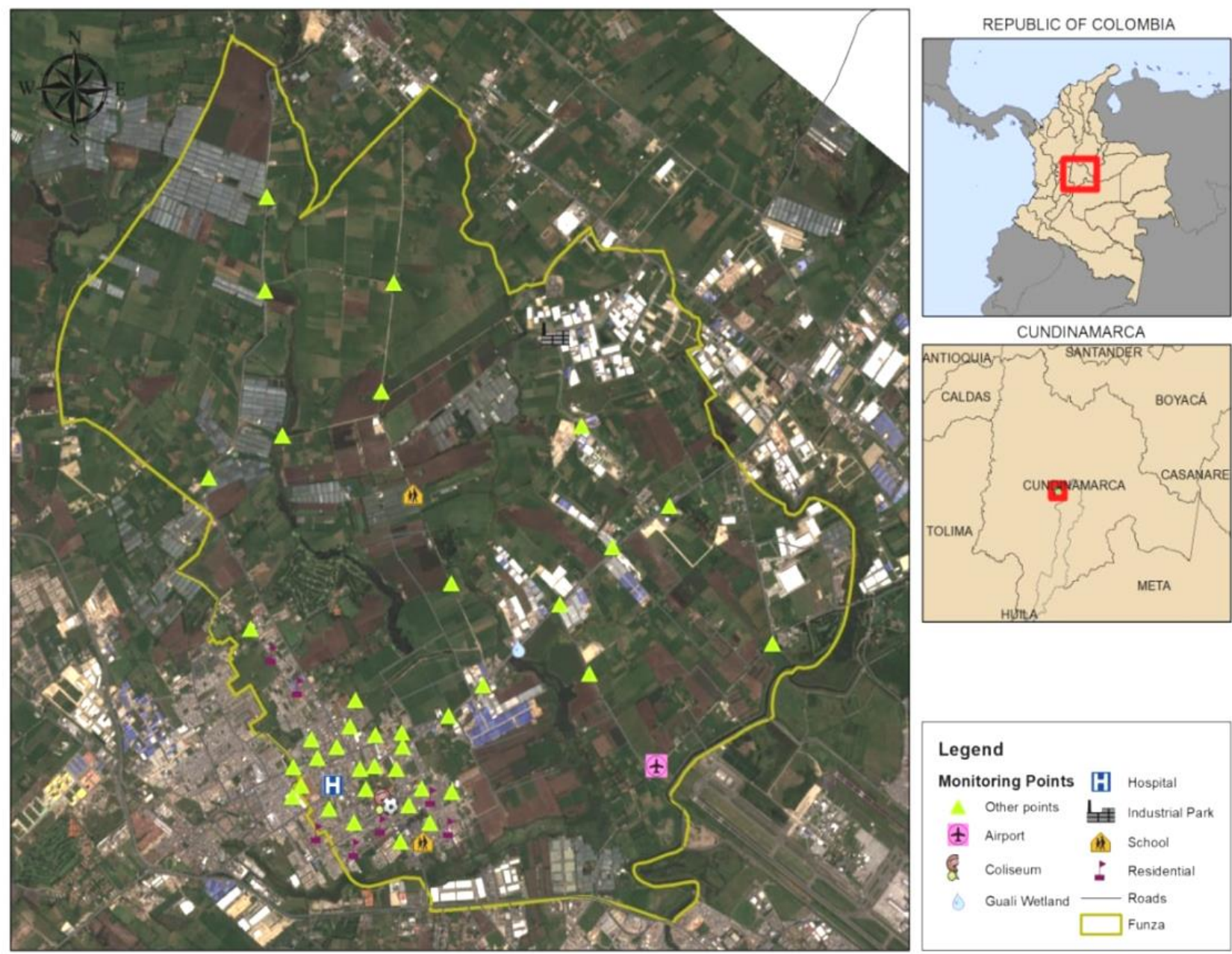

Figure 1. Location of the sampling points for environmental noise in Funza, Cundinamarca 


\begin{tabular}{ccc}
\hline Zone & Subzone & $\begin{array}{c}\text { Maximum allowed } \\
\text { environmental } \\
\text { noise levels - dB(A) } \\
\text { Day }\end{array}$ \\
Night
\end{tabular}
Source: Resolution 627/2006. Ministry of Environment and Sustainable Development (Colombia)

\subsection{Land cover characterization}

The land cover classification was based on a Sentinel -2 satellite image from 2018 (USGS Earth Explorer, 2019) (Figure 1). The image was analyzed with the software ArcGIS 10.5 following the Corine Land Cover methodology adapted to Colombia. This method allows classifying land uses through main levels (artificial surfaces, agricultural areas, forest and semi-naturals areas, wetlands, and water bodies), each level with a more specific category than the previous one [20], for this study third level land cover classification was determined. The analysis of the data is based on three maps of land cover use.

\subsection{Noise mapping}

Day and night time noise maps were generated with the software ArcGIS 10.5 based on the spatial distribution of the sampling points, ArcGIS ${ }^{\circ}$ is a Geographic information system, a computer-based tool by which can visualize, store, process, and analyze geographic data, to finally, create maps and reports [21]. Each sampling point has the following information: sound pressure levels and geographic coordinates. Sound pressure levels of day and night time were interpolated with the Inverse Distance Weighthing (IDW) method, available within the Geostatistical Analyst tool of ArcGIS 10.5. IDW is very popular techique in GIS, estimates are made from values at nearby locations weighted only by distance from the interpolation site, this method is classified as a deterministic approach allowing to interpolate the information available from sampling points to non measured sections of the study area [21]. The simplified formula for IDW as shown in Eq. (1).

$$
V_{0}=\frac{\sum_{i}^{n} 1\left(\frac{V_{i}}{D_{i}}\right)}{\sum_{i}^{n} 1\left(\frac{1}{D_{i}}\right)}
$$

$\mathrm{V}_{0}$ is the predictable value at point $0, \mathrm{~V}_{\mathrm{i}}$ is the value at control point, $\mathrm{D}_{\mathrm{i}}$ is the distance between control point and 0 , and $\mathrm{n}$ is the number of known values used in the evaluation [17].

The output was classified according with the environmental regulation of Colombia, grouping the classes every $5 \mathrm{~dB}(\mathrm{~A})$. The noise distribution according to land use in Funza was analyzed. For this, the environmental noise and land use cover maps were overlapped. For each class it was evaluated if the noise values comply with the regulations. Additionally, it was analyzed if there is a correlation between land use and noise.

\section{RESULTS}

\subsection{Continuous equivalent sound pressure levels in Funza}

During daytime $71 \%$ of the sampling points the sound pressure levels are below the maximum allowed. Whereas $29 \%$ of the sampling points do not comply (Figure 2 ). On the other hand, during night time sound pressure levels did not have a significant change. In $88 \%$ of the sampling points these levels are above the maximum allowed, meanwhile only $12 \%$ of these points comply (Figure 3). Regulations are more restrictive regarding night time levels, at this time should be quieter as rest is needed. The results are not as expected, at some points noise levels were higher than at day time.

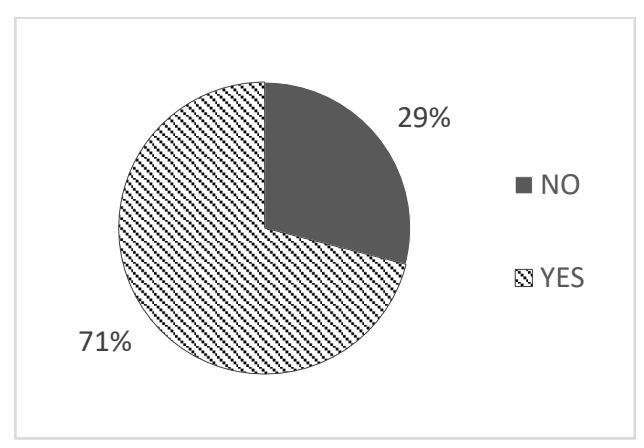

Figure 2. Sound pressure levels day time compliance

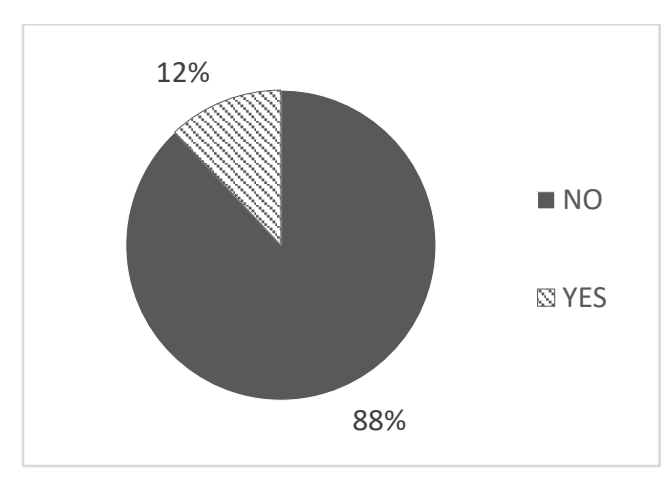

Figure 3. Sound pressure levels night time compliance 
It is important to underline that sound pressure levels in zone A should not exceed $55 \mathrm{~dB}(\mathrm{~A})$. However, in this case the sound pressure levels reached $64 \mathrm{~dB}(\mathrm{~A})$. In this zone is located the hospital and is affected by the traffic in the road connecting the towns of Funza and Siberia.

One of the points with high sound pressure levels is El Dorado airport. This point has $84 \mathrm{~dB}(\mathrm{~A})$, which means $4 \mathrm{~dB}$ (A) higher that the level allowed. The industrial parks Big Cola and Pepsico factory should be in the subzone related to industrial and commercial activities; however, the sampling points were close to a main route and a highway nearby. For this reason, the sound pressure levels were compared with sector $\mathrm{C} 5$, leading to a less restrictive maximum levels allowed $(80 \mathrm{~dB}(\mathrm{~A}))$. The sound pressure levels for these sites were 72.3 and $74.3 \mathrm{~dB}(\mathrm{~A})$ respectively. In total, six schools were monitored; three of them comply according to the maximum levels allowed for zone B.

\subsection{Land use cover map of Funza}

Figure 4 shows the classification level 3 of Corine Land Cover adapted to Colombia. This level includes 13 land use types: continuous urban fabric, discontinuous urban fabric, industrial or commercial units, road and rail network, airports, sport and leisure facilities, greenhouses, pastures, wooded pastures, crop matrix, pastures and crops matrix, wetlands, and water courses.

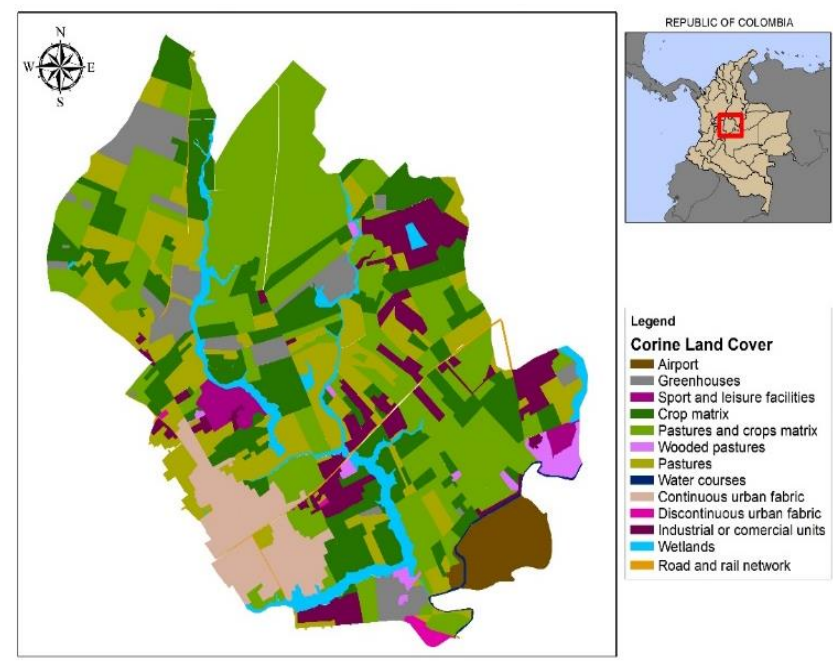

Figure 4. Land use cover map of Funza

\subsection{Noise map of Funza}

Figure 5 shows the noise map during day time in Funza. The sound pressure levels ranged between $45 \mathrm{~dB}(\mathrm{~A})$ to $85 \mathrm{~dB}(\mathrm{~A})$. Lowest levels were measured in areas without industries or greenhouses, far away of the city centre. In the urban zone sound pressure levels ranged between $50 \mathrm{~dB}(\mathrm{~A})$ and $65 \mathrm{~dB}(\mathrm{~A})$, the lowest $(45 \mathrm{~dB}(\mathrm{~A})$ to $55 \mathrm{~dB}(\mathrm{~A}))$ were measured in some residential areas. Meanwhile, the highest sound levels (70 $\mathrm{dB}(\mathrm{A})$ to $80 \mathrm{~dB}(\mathrm{~A})$ ) were recorded in the road connecting the towns of Funza and Siberia.

In the rural zone sound pressure levels vary from $55 \mathrm{~dB}(\mathrm{~A})$ and $70 \mathrm{~dB}(\mathrm{~A})$. However, it is important to underline that in one of the points (greenhouse - flora) sound pressure levels reached $71.3 \mathrm{~dB}(\mathrm{~A})$ because of traffic flow in and out of the site during the measurements.
Celta industrial complex is located in a rural area, however high levels were found due to heavy cargo transport. The highest sound pressure levels $(75 \mathrm{~dB}(\mathrm{~A})$ to $85 \mathrm{~dB}(\mathrm{~A}))$ were measured at the South West of Funza. This is because at this location is the beginning of the landing strip of El Dorado airport. Additionally, there are more points with high sound pressure levels as Funza is influenced by the landing route. One of these points is the bridge of Humedal Guali which reached $78.31 \mathrm{~dB}(\mathrm{~A})$.

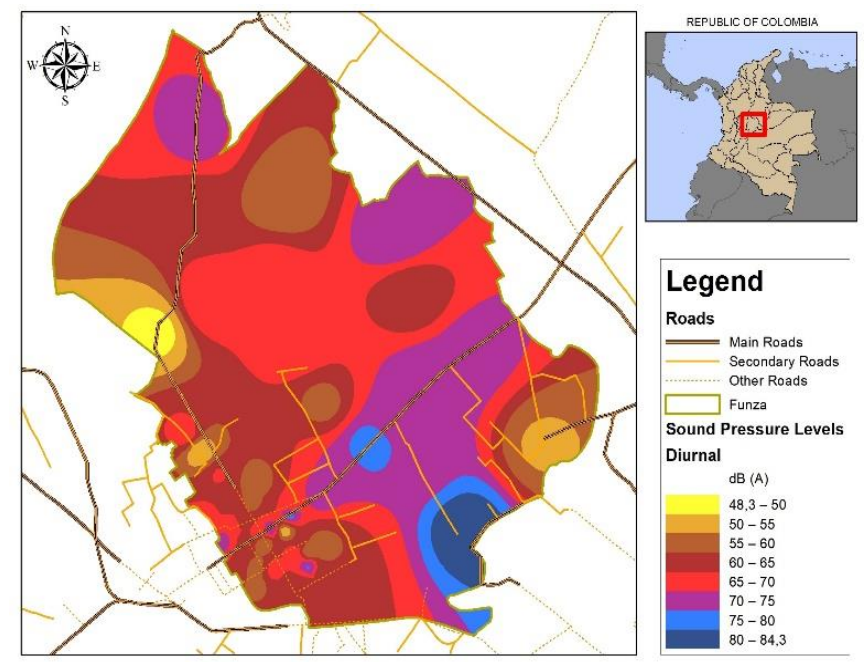

Figure 5. Environmental noise map during day time in Funza

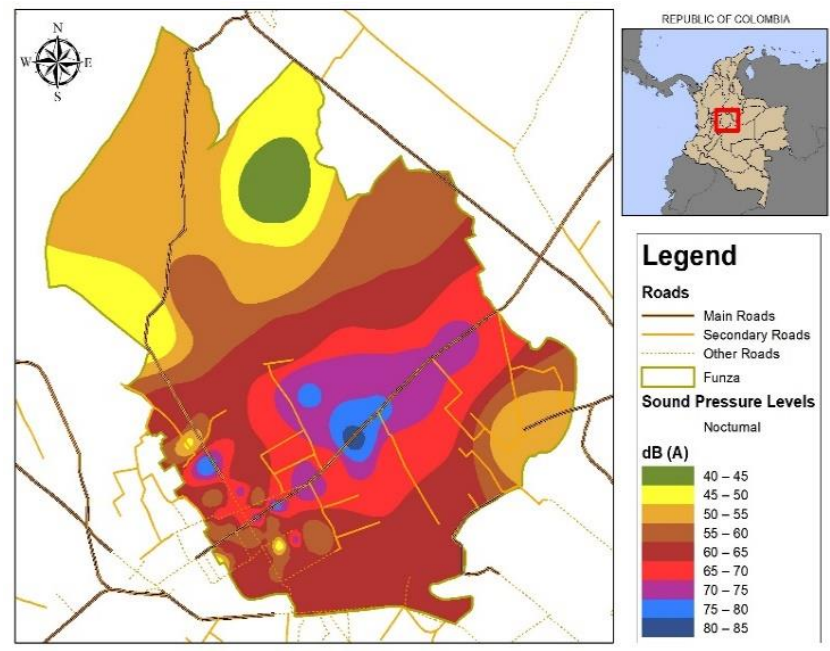

Figure 6. Environmental noise map during night time in Funza

Sound pressure levels during night time ranged between 40 to $85 \mathrm{~dB}(\mathrm{~A})$ (Figure 6). The lowest noise levels (45 to $80 \mathrm{~dB}$ (A)) were recorded in the rural area at North West. In this zone, the lowest levels were found in residential areas while the highest in the main road of Funza. At night time the point located at the bridge of Humedal Guali also had the highest sound pressure level $(81.3 \mathrm{~dB}(\mathrm{~A}))$.

The main highways showed the highest sound pressure levels in both, day and night time noise maps. This is because high traffic flows in two main roads of Funza. The first one connects Funza with industrial parks and the main road to Bogotá (from South West to North East). In this road there is high cargo movement from and to industrial zones and warehouses, public transport and other vehicles. The second 
road known as Calle 15 crosses the urban area of Funza from South East to North West. In this road run public transport and other vehicles.

\subsection{Relationship between sound pressure levels and land use cover in Funza}

Figure 7 shows noise distribution (day time) according to the land use cover in Funza. In this map the Airport class has noise pressure levels between 70 and $80 \mathrm{~dB}(\mathrm{~A})$. On the other hand Greengouses has different noise pressure levels: 55 $\mathrm{dB}(\mathrm{A}), 60 \mathrm{~dB}(\mathrm{~A})$ and $70 \mathrm{~dB}(\mathrm{~A})$, meanwhile in Recreational Facilities noise pressure levels reached $55 \mathrm{~dB}(\mathrm{~A})$.

The class road and railway network were represented mainly by the road connecting Funza and Siberia and the road Calle 15. In the first one, the sound pressure levels ranged between 70 and $75 \mathrm{~dB}(\mathrm{~A})$. Meanwhile, in the second one, the levels varied from 60 to $65 \mathrm{~dB}(\mathrm{~A})$. The reason of these values is the high traffic flow in the two roads.

Bogotá river flows in the South East side of Funza and represents the class Rivers. This class is influenced by the landing route of $\mathrm{El}$ Dorado airport and has high sound pressure levels (70 to $80 \mathrm{~dB}(\mathrm{~A}))$. The class Swamp Areas is represented by Humedal Gualí. As it crosses Funza, there was not possible to determine specific sound pressure levels for this class. In this case, the sound pressure levels vary according to the land cover surrounding the wetland.

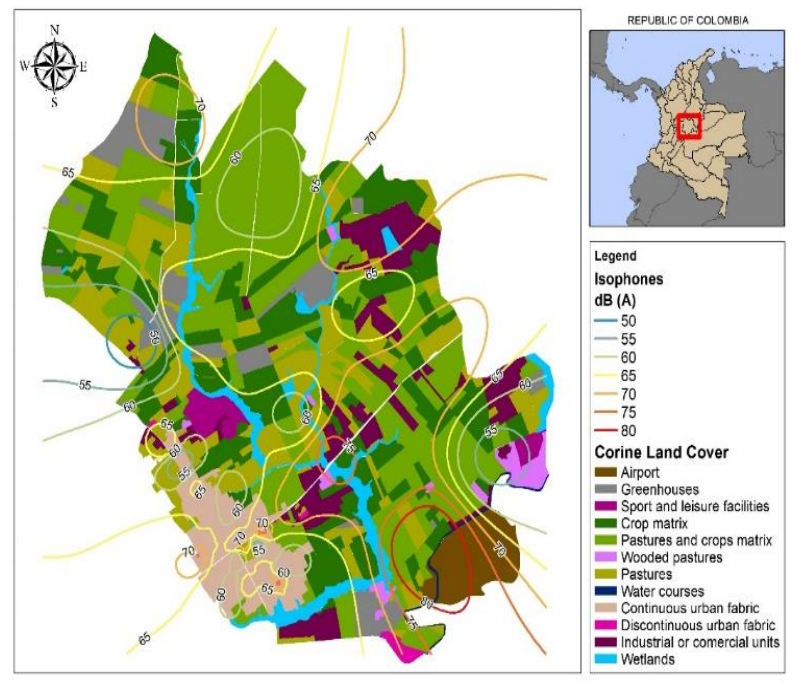

Figure 7. Day time isophones and land use cover in Funza

The class continuous urban infrastructure did not reach high levels (55 to $65 \mathrm{~dB}(\mathrm{~A})$ ) because is mostly composed by residential areas. On the other hand, the class Industrial or Commercial Areas reached sound pressure levels between 65 and $75 \mathrm{~dB}(\mathrm{~A})$.

The correlation between sound pressure levels distribution during night time and land use cover in Funza is shown in Figure 8. During night time, the sound pressure levels of most of the land use classes increased by $5 \mathrm{~dB}(\mathrm{~A})$. Contrary, sound pressure levels of Airports decreased during night time to $60 \mathrm{~dB}(\mathrm{~A})$

Pastures, Crops matrix, and pastures and crops matrix are distributed all over Funza, for this reason it is difficult to determine correlations between noise and land use for these classes. In these areas there is not a sound barrier and the noise behaviour trend to vary for this reason. Besides, during field work it was clear that the airplane pathways affect the sound pressure levels. However, it is not clear yet as noise trends to dissipate in the atmosphere [22].

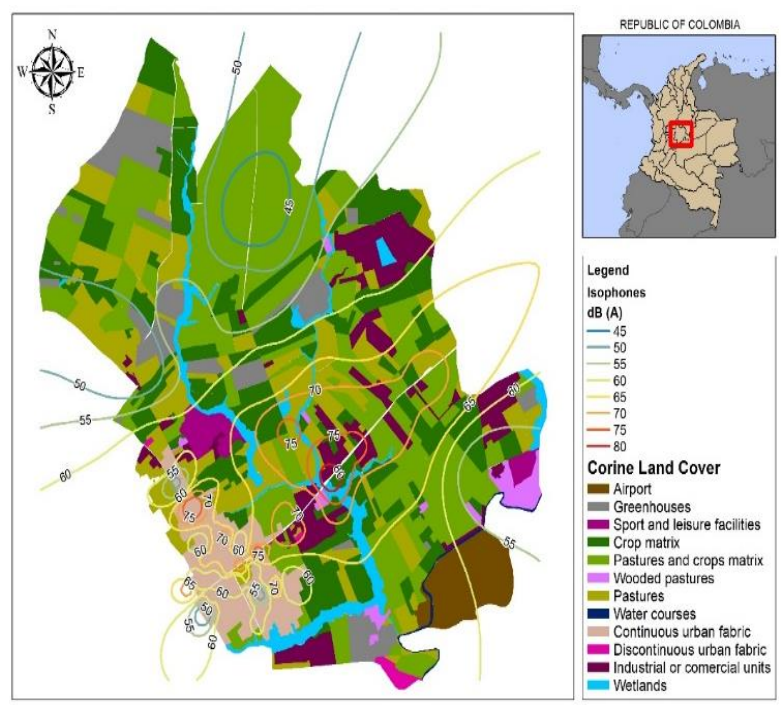

Figure 8. Night time isophones and land use cover in Funza

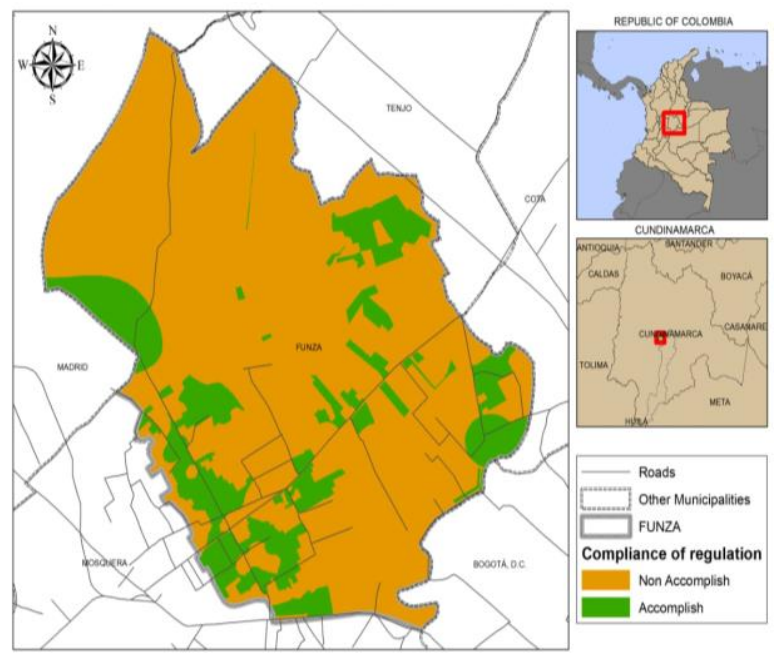

Figure 9. Regulation compliance during day time with respect to land use in Funza

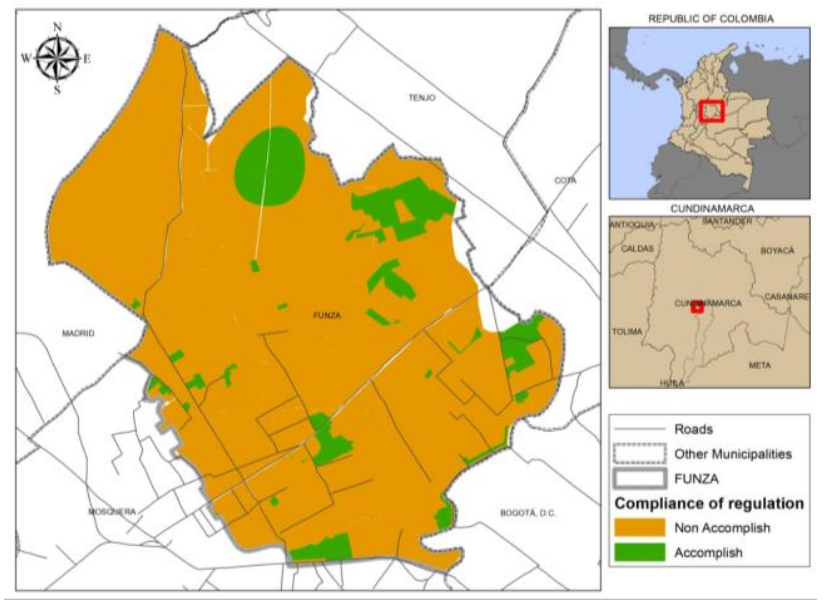

Figure 10. Regulation compliance during night time with respect to land use in Funza 
Figures 9 and 10 show the regulation compliance with respect to land use in Funza. At day time 18\% of Funza comply while at night time is only $9.6 \%$. The low compliance percentage is because the high traffic that affect all over Funza, besides the landing route of El Dorado airport. These two factors increase the sound pressure levels in crop zones.

\section{CONCLUSIONS}

The highest sound pressure levels were recorded in the sampling points along the main road. These points also covered the classes Road and Railway network during both, day and night time (Figure 5 and Figure 6). The high sound pressure levels were related to high traffic from and towards industrial zones and Bogotá. However, the sound pressure levels measured in these points complied the regulation for Sector C5 (daytime: $80 \mathrm{~dB}(\mathrm{~A})$; nigh time: $70 \mathrm{~dB}(\mathrm{~A})$ ).

Airports are relevant noise sources influencing cities and towns nearby. El Dorado airport influenced sound pressure levels in Funza, due to take off and landing of airplanes.

The low percentage of regulation compliance found in this study could lead to health issues for Funza population.

The spatial analysis of sound pressure levels from land use cover could help to mitigate impacts of noise pollution. Only if there is a complete survey of the study area and considering that in the towns most of the land use cover is mixed.

The territorial planning of each city is fundamental for the noise impact mitigation. In addition, land use planning is a tool that helps to reduce the exposure and frequency of population. Thus, city planning is a relevant strategy because it orders the land uses, distancing those with the highest noise generation from sensitive receptors. The planning of Funza's territory should be carried out together with the city of Bogotá. This because the results of the study showed that Bogotá influences the sound pressure levels in Funza.

Hours on traffic restriction must be implemented at night time since these are the most sensitive hours and where the greatest discomfort occurs. Finally, based on these results, it is recommended that the environmental authorities start annual measurements of environmental noise and noise emission in Funza, as well as noise maps production as a tool to mitigate noise pollution impacts.

\section{ACKNOWLEDGEMENTS}

The authors thank to Seruans Environment S.A.S for providing the equipment for environmental noise measurements.

\section{REFERENCES}

[1] Lee, H.P., Garg, S., Lim, K.M., (2020). Crowdsourcing of environmental noise map using calibrated smartphones. Applied Acoustics, 160: 107130. https://doi.org/10.1016/j.apacoust.2019.107130

[2] Paschalidou, A.K., Kassomenos, P., Chonianaki, F., (2019). Strategic Noise Maps and Action Plans for the reduction of population exposure in a Mediterranean port city. Science of the Total Environment, 654: 144-153. https://doi.org/10.1016/j.scitotenv.2018.11.048

[3] Wang, H., Chen, H., Cai, M., (2018). Evaluation of an urban traffic Noise-Exposed population based on points of interest and noise maps: The case of Guangzhou. Environmental Pollution, 239: 741-750. https://doi.org/10.1016/j.envpol.2017.11.036

[4] Alonso, G., Benito, A., Boto, L., (2017). The efficiency of noise mitigation measures at European airports. Transportation Research Procedia, 25: 103-135. https://doi.org/10.1016/j.trpro.2017.05.385

[5] Berglund, B., Lindvall, T., Schwela, D. GUÍAS PARA EL RUIDO URBANO. http://cornare.gov.co/SIAR/aire/RUIDO/NORMATIVA /Guias-Ruido-Urbano-OMS-1999.pdf/, accessed on Jan. 30, 2020.

[6] Ramírez González, A., Domínguez Calle, E.A. (2011). El ruido vehicular urbano: Problemática agobiante de los países en vías de desarrollo. Revista de la Academia Colombiana de Ciencias Exactas, Físicas y Naturales, 35(137): 509-530.

[7] Yepes, D., Gómez, M., Sánchez, L., Jaramillo, A. (2009). Metodología de elaboracón de mapas acústicos como herramienta de gestión del ruido urbano-caso Medellín. Dyna (Colombia), 76(158): 29-40.

[8] WHO \& JRC European Commission. (2011). Burden of disease from environmental noise-Quantification of healthy life years lost in Europe. WHO Regional Office for Europe.

[9] González Sánchez, Y., Fernández Díaz, Y. (2014). Noise pollution in schools: Its effect on the health of students and teachers. Revista Cubana de Higiene y Epidemiologia, 52(3): 402-410.

[10] WHO - Escuchar sin riesgos. https://www.who.int/pbd/deafness/activities/MLS_Broc hure_Spanish_lowres_for_web.pdf?ua $=1$, accessed on Jan. 30, 2020.

[11] CAR - Mapa de ruido, municipio de Girardot. https://www.car.gov.co/uploads/files/5b32a013443e2.p df, accessed on Jan. 30, 2020.

[12] European Parliament and Council of the European Union - Assessment and management of environmental noise (EU Directive). https://eur-lex.europa.eu/legalcontent/EN/TXT/PDF/?uri=CELEX:02002L0049 20200325\&from=EN, accessed on Jan. 30, 2020.

[13] Ko, J.H., Chang, S. Il, Lee, B.C. (2011). Noise impact assessment by utilizing noise map and GIS: A case study in the city of Chungju, Republic of Korea. Applied Acoustics, 72(8): 544-550. https://doi.org/10.1016/j.apacoust.2010.09.002

[14] Asensio Rivera, C. - Mapas de ruido. Estrategia y concienciación en la lucha contra el ruido. http://oa.upm.es/9889/ accessed on Jan. 30, 2020.

[15] Liu, Y., Goudreau, S., Oiamo, T., Rainham, D., Hatzopoulou, M., Chen, H., Davies, H., Tremblay, M., Johnson, J., Bockstael, A., Leroux, T., Smargiassi, A. (2020). Comparison of land use regression and random forests models on estimating noise levels in five Canadian cities. Environmental Pollution, 256: 113367. https://doi.org/10.1016/j.envpol.2019.113367

[16] Nakano, Y., Senzaki, M., Ishiyama, N., Yamanaka, S., Miura, K., Nakamura, F. (2018). Noise pollution alters matrix permeability for dispersing anurans: Differential effects among land covers. Global Ecology and Conservation, 16 : e00484. https://doi.org/10.1016/j.gecco.2018.e00484

[17] Pelletier, C., Valero, S., Inglada, J., Champion, N., Sicre, 
C.M., Dedieu, G. (2017). Effect of training class label noise on classification performances for land cover mapping with satellite image time series. Remote Sensing, 9(2): 173. https://doi.org/10.3390/rs9020173

[18] Iglesias Merchan, C., Diaz-Balteiro, L. (2013). Noise pollution mapping approach and accuracy on landscape scales. Science of the Total Environment, 449: 115-125. https://doi.org/10.1016/j.scitotenv.2013.01.063

[19] Ministerio de Ambiente y Desarrollo Sostenible Resolución $\quad 627 \quad$ de 2006 https://www.minambiente.gov.co/images/Asuntosambie ntalesySectorialyUrbana/pdf/emisiones_atmosfericas_c ontaminantes/norma_ruido/Resolucion_627_de_2006__Norma_nacional_de_emision_de_ruido.pdf, accessed on Jan. 30, 2020.
[20] IDEAM - Leyenda Nacional de Coberturas de la Tierra. Metodología CORINE Land Cover adaptada para Colombia Escala 1:100.000. 2010. http://siatac.co/c/document_library/get_file?uuid=a6462 9ad-2dbe-4e1e-a561-fc16b8037522\&groupId=762, accessed on Jan. 30, 2020.

[21] Bajjali, W. (2018). ArcGIS for Environmental and Water Issues. Springer International Publishing AG.

[22] Tarrero, A. (2002). Propagación del sonido en bosques. Análisis comparativo de las medidas in situ, en laboratorio y de los valores predichos por un modelo. http://www.cervantesvirtual.com/descargaPdf/propagaci on-del-sonido-en-bosques-analisis-comparativo-de-lasmedidas-in-situ-en-laboratorio-y-de-los-valorespredichos-por-un-modelo--0/, accessed on Jan. 30, 2020. 